\section{Vermicompost Affects Soil Properties and Spinach Growth, Physiology, and Nutritional Value}

\author{
Chenping $\mathrm{Xu}^{1}$ and Beiquan Mou \\ U.S. Department of Agriculture, Agricultural Research Service, U.S. \\ Agricultural Research Station, 1636 East Alisal Street, Salinas, CA 93905
}

Additional index words. Spinacia oleracea, antioxidant, chlorophyll, drench, phytochemicals, soil amendment, worm castings

\begin{abstract}
The use of vermicompost to improve soil fertility and enhance crop yield has gained considerable momentum due to its contribution to agroecological sustainability. Short-term (35 days after transplanting) effects of vermicompost, applied either as a soil amendment $(5 \%$ and $10 \%, v / v)$ or a drench $(40 \mathrm{~mL}$ of vermicompost extract at $0,14,21$, and 28 days after transplanting), on soil properties and spinach plants (Spinacia oleracea L.) were evaluated in a greenhouse. After harvesting, the amendments left high residual levels of nutrients, organic matter and carbon, and increased soil cation exchange capacity (CEC) and water-holding capacity (WHC). Drench treatment of unamended soil increased soil nutrients, CEC, and WHC. All vermicompost treatments, especially amendment at $10 \%$ rate, increased leaf number, area, fresh and dry weight (FW and DW), shoot FW and DW, root DW, and water use efficiency (WUE). Vermicompost increased leaf chlorophyll content, and photochemical efficiency, yield, and electron transport rate (ETR) of mature leaves, as well as increased leaf succulence, and carotenoid, protein, and amino acid content. Vermicompost soil amendment reduced phenolics and flavonoids, leading to lower antioxidant capacity, whereas drench treatment only decreased betacyanin content. Vermicompost improved soil fertility, prompted leaf production, delayed leaf senescence, and enhanced growth of spinach. It also favorably influenced spinach quality by increasing leaf succulence and carotenoid, protein, and amino acids content, although it, as soil amendment, reduced flavonoid content leading to low antioxidant capacity.
\end{abstract}

Soil organic matter plays a key role to achieve sustainability in agricultural production, because it possesses many desirable properties such as high WHC, CEC, ability to sequester contaminants, and beneficial effects on the physical, chemical, and biological characteristics of soil (Herrick, 2000; Liu et al., 2006). In this context, the use of organic soil amendments to improve soil fertility and enhance crop yield has gained considerable momentum for agroecological sustainability (D'Hose et al., 2014; Hargreaves et al., 2008).

Vermicomposting is a bio-oxidative process that uses earthworms and microorganisms for solid organic waste reclamation. The

\footnotetext{
Received for publication 15 Mar. 2016. Accepted for publication 8 May 2016.

We thank Worm Power for providing vermicompost products. The technical assistance of Phi Diep and Frances Wong, and critical review by James McCreight and Renee Eriksen are greatly appreciated.

Mention of trade names or commercial products in this publication is solely for the purpose of providing specific information and does not imply recommendation or endorsement by the U.S. Department of Agriculture.

USDA is an equal opportunity provider and employer.

${ }^{1}$ Corresponding author. E-mail: chenping.xu@ ars.usda.gov.
}

microorganisms, both in the earthworm guts and in the feedstock, are responsible for the biochemical degradation of the organic matter, whereas the earthworms are responsible for the fragmentation of the substrate, which increases the surface area exposed to the microorganisms. The product, vermicompost, is a finely divided mature peatlike material with high porosity, aeration, drainage, WHC, and microbial activity (Srivastava et al., 2011). It can be applied as soil amendment to improve soil fertility by increasing soil organic matter, CEC, and nutrient content, and improve soil structure (Arancon et al., 2006a; Srivastava et al., 2011). Many studies indicated that vermicompost is preferable to compost to improve soil quality (Fornes et al., 2012; Tognetti et al., 2005).

There are many reports of positive effects of vermicompost, as soil amendments or leachate, on many crops, including parsley (Petroselinum crispum Mill.) (Peyvast et al., 2008b), tomato (Solanum lycopersicum L.) (Arancon et al., 2003a, 2012), bell pepper (Capsicum anuum grossum L.) (Arancon et al., 2003a), lettuce (Lactuca sativa L.) (Arancon et al., 2012), mustard (Brassica L.) (Srivastava et al., 2011), strawberry (Fragaria ananasa L.) (Arancon et al., 2003a, 2004), ryegrass (Lolium perenne L.) (Tognetti et al., 2005), sorghum (Sorghum bicolor L.) (Gutiérrez-Miceli et al., 2008), petunias (Petunias sp.) (Arancon et al., 2008), cow pea (Vigna unguiculata L.), banana (Musa acuminate L.), and cassava (Manihot esculenta L.) (Padmavathiamma et al., 2008). However, literature about the effects of vermicompost on spinach (Spinacia oleracea L.), an important salad vegetable with large quantities of bioactive compounds and nutrients, is very scarce and focused on growth only (Peyvast et al., 2008a). Our objective was to assess the short-term effects of vermicompost as soil amendments or leachate on soil properties, and spinach growth, physiology, and nutritional value.

\section{Materials and Methods}

Plant materials and treatments. Two trials, each with four replications, were conducted from 30 Mar. to 14 May 2015 and 13 Apr. to 28 May 2015, in a greenhouse located in Salinas, $\mathrm{CA}$ (lat. $36^{\circ} 40^{\prime} 40^{\prime \prime} \mathrm{N}$, long. $121^{\circ} 39^{\prime} 20^{\prime \prime} \mathrm{W}$ ). The average temperature inside the greenhouse during the course of the trials ranged from $15{ }^{\circ} \mathrm{C}$ night to $34{ }^{\circ} \mathrm{C}$ day and relative humidity ranged from $20 \%$ to $80 \%$. The greenhouse was supplemented with light of a 12-h photoperiod (Sun System 3; Sunlight Supply, Vancouver, WA).

There were four treatments in this experiment: 1) Control: field soil (sandy loam) without amendments; 2) Drench: plants were drenched with $40 \mathrm{~mL}$ of commercial liquid vermicompost extraction (Worm Power, Avon, NY) at 0, 14, 21, and $28 \mathrm{~d}$ after transplanting; 3) 5Ver: soil mixed with $5 \%(\mathrm{v} / \mathrm{v})$ of commercial granular vermicompost (Worm Power, Avon, NY); 4) 10Ver: soil mixed with $10 \%(\mathrm{v} / \mathrm{v})$ of granular vermicompost. Plastic pots (diameter: $15 \mathrm{~cm}$; depth: $17 \mathrm{~cm}$ ) with a single, bottom drain hole were filled with $3 \mathrm{~kg}$ different mixture of soil and vermicompost amendments, and watered just to field capacity 2 weeks before transplanting. Uniform-sized spinach seedlings (cv. Crocodile) were transplanted into pots $10 \mathrm{~d}$ after sowing in rock wool cells (Grodan Group, Roermond, Netherlands). Plants were thinned to one plant per pot 1 week after transplanting. Plants were irrigated twice weekly and irrigation volumes were determined by weighing each pot at field capacity and again just before irrigation. The weight loss per pot was assumed to equal total evapotranspiration (ET), and its equivalent amount was applied for each pot. Therefore, the water applied was very close to ET and the leached water and nutrients were ineligible.

Soil and compost analysis. The untreated field soil and vermicompost samples were collected before treatments were applied, and the soil samples from different treatments were also collected using a soil sampler after harvesting. One soil core (diameter: $2.6 \mathrm{~cm}$; length: $15 \mathrm{~cm}$ ) was collected from each pot and four soil cores from each treatment were mixed together as one composite sample for determination of macro- and micronutrients, $\mathrm{pH}$, electrical conductivity (EC), organic matter and carbon, CEC, and WHC 
by a commercial laboratory (Soil Control Laboratories, Watsonville, CA).

Growth and physiology measurements. Five weeks after transplanting in each trial, leaf maximum photochemical efficiency $\left(\mathrm{F}_{\mathrm{v}} / \mathrm{F}_{\mathrm{m}}\right)$, photochemical yield [Y(II)], and ETR were measured with a fluorometer

(MINI-PAM-II fluorometer; Heinz Walz, Effeltrich, Germany) on the first, second, and third pair of leaves from the bottom of each plant. Leaf $F_{v} / F_{m}$ was measured after leaves were adapted in darkness for $30 \mathrm{~min}$. Then plants were harvested to measure leaf number, area, FW and DW, shoot FW and

Table 1. Physical and chemical properties of initial soil and granular vermicompost before treatment and soil from each treatment after harvesting.

\begin{tabular}{|c|c|c|c|c|c|c|}
\hline \multirow[b]{2}{*}{ Properties } & \multicolumn{2}{|c|}{ Initial } & \multicolumn{4}{|c|}{ After harvest } \\
\hline & Soil & Vermicompost & Soil & Drench $^{z}$ & $5 \mathrm{Ver}$ & $10 \mathrm{Ver}$ \\
\hline Total N (\%) & - & 4.0 & - & - & - & - \\
\hline Available $\mathrm{N}\left(\mathrm{mg} \cdot \mathrm{kg}^{-1}\right)$ & 48 & - & 6.0 & 7.0 & 6.0 & 10.0 \\
\hline $\mathrm{NH}_{4}-\mathrm{N}\left(\mathrm{mg} \cdot \mathrm{kg}^{-1}\right)$ & 4.6 & 17 & 4.7 & 4.7 & 4.4 & 6.6 \\
\hline $\mathrm{NO}_{3}-\mathrm{N}\left(\mathrm{mg} \cdot \mathrm{kg}^{-1}\right)$ & 43 & 8,000 & $<2$ & 2.3 & $<2$ & 3.2 \\
\hline $\mathrm{P}\left(\mathrm{mg} \cdot \mathrm{kg}^{-1}\right)$ & 39 & 7,300 & 32 & 40 & 51 & 61 \\
\hline $\mathrm{K}\left(\mathrm{mg} \cdot \mathrm{kg}^{-1}\right)$ & 79 & 34,000 & 67 & 80 & 140 & 240 \\
\hline $\mathrm{Ca}\left(\mathrm{g} \cdot \mathrm{kg}^{-1}\right)$ & 1.0 & 39 & 1.0 & 1.2 & 1.1 & 1.1 \\
\hline $\mathrm{Mg}\left(\mathrm{mg} \cdot \mathrm{kg}^{-1}\right)$ & 140 & 10,000 & 130 & 160 & 150 & 170 \\
\hline $\mathrm{SO}_{4}\left(\mathrm{mg} \cdot \mathrm{kg}^{-1}\right)$ & 32 & 6,200 & 16 & 25 & 24 & 48 \\
\hline $\mathrm{Cu}\left(\mathrm{mg} \cdot \mathrm{kg}^{-1}\right)$ & 0.53 & 1,000 & 0.56 & 0.72 & 2.0 & 2.8 \\
\hline $\mathrm{Zn}\left(\mathrm{mg} \cdot \mathrm{kg}^{-1}\right)$ & 2.6 & 250 & 2.9 & 3.5 & 3.4 & 3.8 \\
\hline $\mathrm{Fe}\left(\mathrm{mg} \cdot \mathrm{kg}^{-1}\right)$ & 32 & 3,400 & 25 & 39 & 33 & 53 \\
\hline $\operatorname{Mn}\left(\mathrm{mg} \cdot \mathrm{kg}^{-1}\right)$ & 13 & 180 & 12 & 14 & 10 & 9.6 \\
\hline $\mathrm{B}\left(\mathrm{mg} \cdot \mathrm{kg}^{-1}\right)$ & 0.27 & 53 & 0.30 & 0.38 & 0.42 & 0.44 \\
\hline $\mathrm{Na}\left(\mathrm{mg} \cdot \mathrm{kg}^{-1}\right)$ & 67 & 9,800 & 66 & 88 & 89 & 120 \\
\hline $\mathrm{Cl}\left(\mathrm{mg} \cdot \mathrm{kg}^{-1}\right)$ & 55 & 13,000 & 28 & 55 & 50 & 95 \\
\hline $\mathrm{pH}$ & 6.8 & 6.7 & 7.3 & 7.3 & 7.3 & 7.3 \\
\hline $\mathrm{EC}^{\mathrm{y}}\left(\mathrm{dS} \cdot \mathrm{m}^{-1}\right)$ & 1.9 & 26.0 & 0.58 & 0.91 & 0.92 & 1.4 \\
\hline Organic matter $(\%)$ & 2.3 & 72 & 2.4 & 2.5 & 2.9 & 3.4 \\
\hline Organic carbon $(\%)$ & 1.4 & 37 & 1.4 & 1.4 & 1.7 & 2.0 \\
\hline Bulk density $\left(\mathrm{g} \cdot \mathrm{mL}^{-1}\right)$ & 1.22 & 0.26 & 1.17 & 1.22 & 1.18 & 1.14 \\
\hline $\operatorname{CEC}(\mathrm{meq} / 100 \mathrm{~g})$ & 6.9 & - & 6.7 & 8.0 & 7.4 & 8.1 \\
\hline WHC ( $\mathrm{g} \mathrm{H}_{2} \mathrm{O} / 100 \mathrm{~g}$ soil $)$ & 7.00 & - & 6.85 & 7.62 & 8.16 & 7.74 \\
\hline $\mathrm{C}: \mathrm{N}$ ratio & - & 9.3 & - & - & - & - \\
\hline
\end{tabular}

${ }^{\mathrm{z} D r e n c h:} 40 \mathrm{~mL}$ of vermicompost extract at 0, 14, 21, and $28 \mathrm{~d}$ after transplanting; 5Ver or 10Ver: soil amended with $5 \%$ or $10 \%(\mathrm{v} / \mathrm{v})$ vermicompost.

${ }^{\mathrm{y}} \mathrm{EC}=$ electrical conductivity $; \mathrm{CEC}=$ cation exchange capacity; $\mathrm{WHC}=$ water-holding capacity.
DW, and root DW. Sample DW was measured after drying at $65^{\circ} \mathrm{C}$ for $3 \mathrm{~d}$. Leaf area was measured with a leaf area meter (CI-202 laser area meter; CID Bio-Science Inc., Camas, WA). WUE was calculated as $\mathrm{WUE}=$ shoot $\mathrm{FW} /$ water used or ET.

Leaf discs were collected using a cork borer from the four largest leaves of each plant to measure relative water content (RWC), specific leaf area (SLA), succulence, chlorophyll content, and nutritional values. Specific leaf area was calculated as SLA $=$ leaf area/DW (Evans, 1972). Leaf RWC was calculated as RWC $(\%)=100 \times$ $[(\mathrm{FW}-\mathrm{DW}) /(\mathrm{TM}-\mathrm{DW})]$, where $\mathrm{TM}$ is turgid mass after being soaked in water for $4 \mathrm{~h}$ at $4{ }^{\circ} \mathrm{C}$ (Barr and Weatherley, 1962). Succulence was calculated as water content per unit leaf area (Longstreth and Nobel, 1979). Leaf pigments were extracted with methanol and absorbance of the extraction was measured at 665,652 , and $470 \mathrm{~nm}\left(\mathrm{~A}_{665}, \mathrm{~A}_{652}\right.$, and $\left.\mathrm{A}_{470}\right)$ with a spectrophotometer (Spectronic Genesys; Spectronic Instruments, Rochester, NY). Chlorophyll a, b, and carotenoid contents $\left(\mathrm{C}_{\mathrm{a}}, \mathrm{C}_{\mathrm{b}}\right.$, and $\left.\mathrm{C}_{\mathrm{x}}\right)$ were calculated using the formula described by Lichtenthaler (1987): $\mathrm{C}_{\mathrm{a}}$ $\left(\mathrm{mg} \cdot \mathrm{L}^{-1}\right)=16.72 \mathrm{~A}_{665}-9.16 \mathrm{~A}_{652} ; \mathrm{C}_{\mathrm{b}}\left(\mathrm{mg} \cdot \mathrm{L}^{-1}\right)=$ $34.09 \mathrm{~A}_{652}-15.28 \mathrm{~A}_{665} ; \mathrm{C}_{\mathrm{x}}\left(\mathrm{mg} \cdot \mathrm{L}^{-1}\right)=$ $\left(1000 \mathrm{~A}_{470}-1.63 \mathrm{C}_{\mathrm{a}}-104.96 \mathrm{C}_{\mathrm{b}}\right) / 221$.

Phytochemical analyses. Leaf samples were soaked in liquid nitrogen immediately after harvest and stored at $-80{ }^{\circ} \mathrm{C}$. Phytochemicals were extracted from $\approx 2 \mathrm{~g}$ of sample material with $15 \mathrm{~mL}$ acidified methanol $(1 \% \mathrm{HCl})$ using a homogenizer
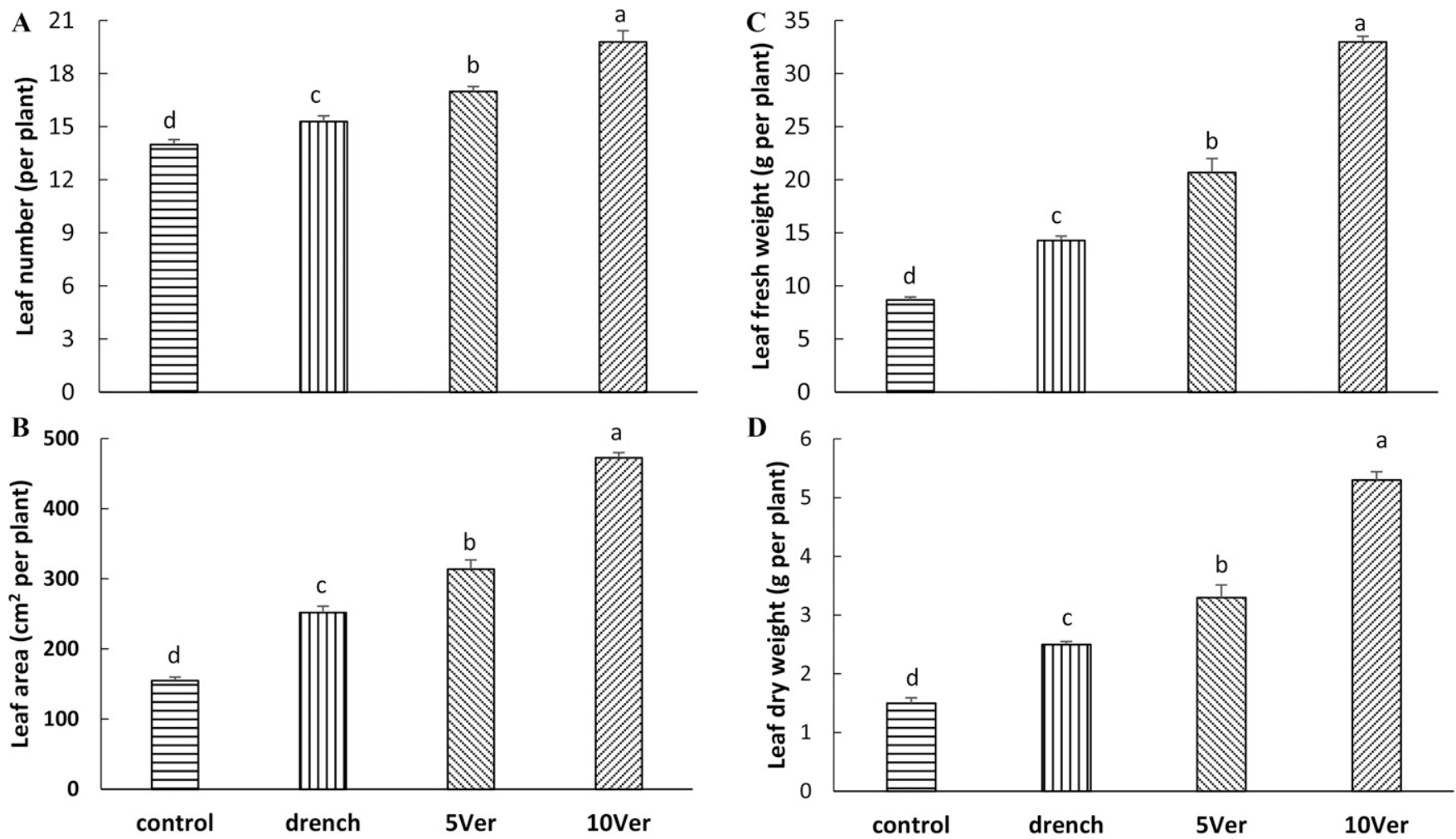

Fig. 1. Effect of vermicompost on spinach leaf number (A), area (B), fresh $(\mathbf{C})$ and dry $(\mathbf{D})$ weight $35 \mathrm{~d}$ after transplanting. The values are means of eight replicates \pm SE. Different letters on top of bars indicate significant difference at $P \leq 0.05$ according to Student's $t$ test. Drench: $40 \mathrm{~mL}$ of vermicompost extract at $0,14,21$, and $28 \mathrm{~d}$ after transplanting; 5Ver or 10 Ver: soil amended with $5 \%$ or $10 \%(\mathrm{v} / \mathrm{v})$ vermicompost. 

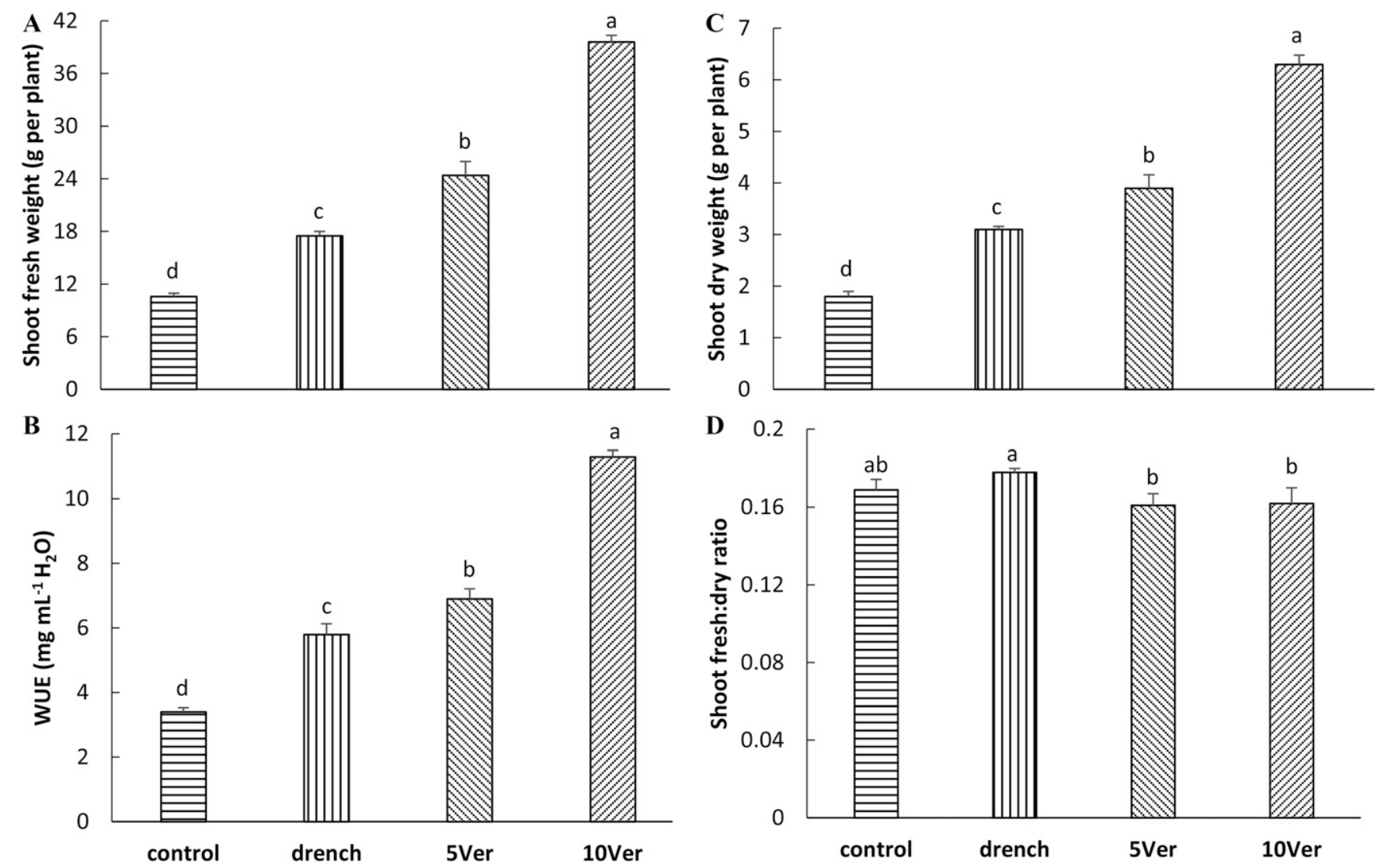

Fig. 2. Effect of vermicompost on spinach shoot fresh weight (A), water use efficiency (WUE; B), dry weight (C), and fresh:dry ratio (D) $35 \mathrm{~d}$ after transplanting. The values are means of eight replicates $\pm \mathrm{SE}$. Different letters on top of bars indicate significant difference at $P \leq 0.05$ according to Student's $t$ test. Drench: $40 \mathrm{~mL}$ of vermicompost extract at $0,14,21$, and $28 \mathrm{~d}$ after transplanting; 5 Ver or 10 Ver: soil amended with $5 \%$ or $10 \%$ (v/v) vermicompost.
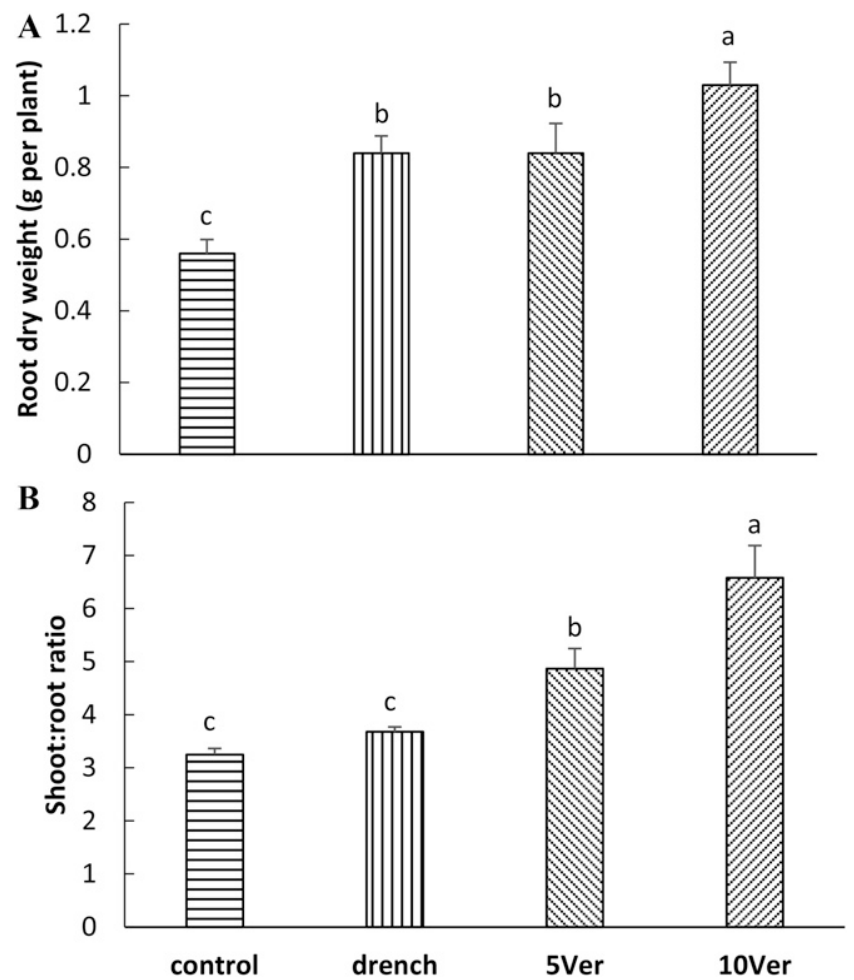

Fig. 3. Effect of vermicompost on spinach root dry weight (A) and shoot:root ratio (B) $35 \mathrm{~d}$ after transplanting. The values are means of eight replicates \pm SE. Different letters on top of bars indicate significant difference at $P \leq 0.05$ according to Student's $t$ test. Drench: $40 \mathrm{~mL}$ of vermicompost extract at $0,14,21$, and $28 \mathrm{~d}$ after transplanting; 5 Ver or 10 Ver: soil amended with $5 \%$ or $10 \%(\mathrm{v} / \mathrm{v})$ vermicompost.
(Polytron; Kinematica AG, Schweiz, Switzerland), then incubated in darkness at $-20^{\circ} \mathrm{C}$ overnight. After centrifuging at $9070 g_{n}$ for $15 \mathrm{~min}$, the supernatant was collected for the analysis of nutrition values. Its $\mathrm{A}_{535}$ was measured for total betacyanin content. Results were calculated using a molar extinction coefficient of 65,000 (Schwartz and von Elbe, 1980). The antioxidant capacity was measured by the method of ferric-reducing ability of plasma (Benzie and Strain, 1996). $10 \mathrm{~mm}$ 2,4,6-tris-2,4,6-tripyridyl-2-triazine (TPTZ) and $20 \mathrm{~mm}$ ferric chloride was diluted in $300 \mathrm{~mm}$ sodium acetate buffer $(\mathrm{pH} 3.6)$ at a ratio of $1: 1: 10$. Extracts $(25 \mu \mathrm{L})$ were added to $2 \mathrm{~mL}$ TPTZ solution, and $\mathrm{A}_{593}$ was determined after 4.5 min reaction. Trolox (6-hydroxy-2,5,7,8-tetramethylchroman-2carboxyl acid) equivalent (TE) standard curve was prepared

For total phenolics content, $0.1 \mathrm{~mL}$ extract was added to a mixture of $0.15 \mathrm{~mL} \mathrm{H}_{2} \mathrm{O}$ and $0.75 \mathrm{~mL}$ of $1: 10$ diluted Folin-Ciocalteu reagent (Sigma-Aldrich, St. Louis, MO). After $6 \mathrm{~min}, 0.60 \mathrm{~mL}$ of $7.5 \%$ (w/v) $\mathrm{Na}_{2} \mathrm{CO}_{3}$ was added and vortexed, then the mixture was incubated at $45^{\circ} \mathrm{C}$ in a water bath for $10 \mathrm{~min}$. Samples were allowed to cool to room temperature before reading $\mathrm{A}_{765}$ (Slinkard and Singleton, 1997). A standard curve was prepared from a freshly made gallic acid equivalent (GAE) solution. For total flavonoid content, $0.20 \mathrm{~mL}$ extract was mixed with 


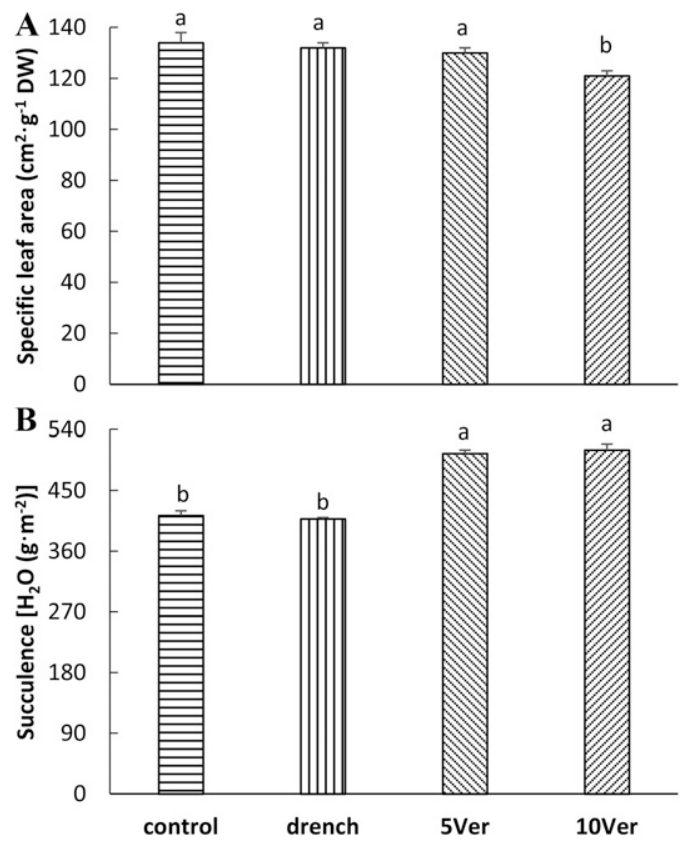

Fig. 4. Effect of vermicompost on spinach specific leaf area (SLA; A), and succulence (B) $35 \mathrm{~d}$ after transplanting. The values are means of eight replicates \pm SE. Different letters on top of bars indicate significant difference at $P \leq 0.05$ according to Student's $t$ test. Drench: $40 \mathrm{~mL}$ of vermicompost extract at $0,14,21$, and $28 \mathrm{~d}$ after transplanting; 5 Ver or 10 Ver: soil amended with $5 \%$ or $10 \%(\mathrm{v} / \mathrm{v})$ vermicompost.
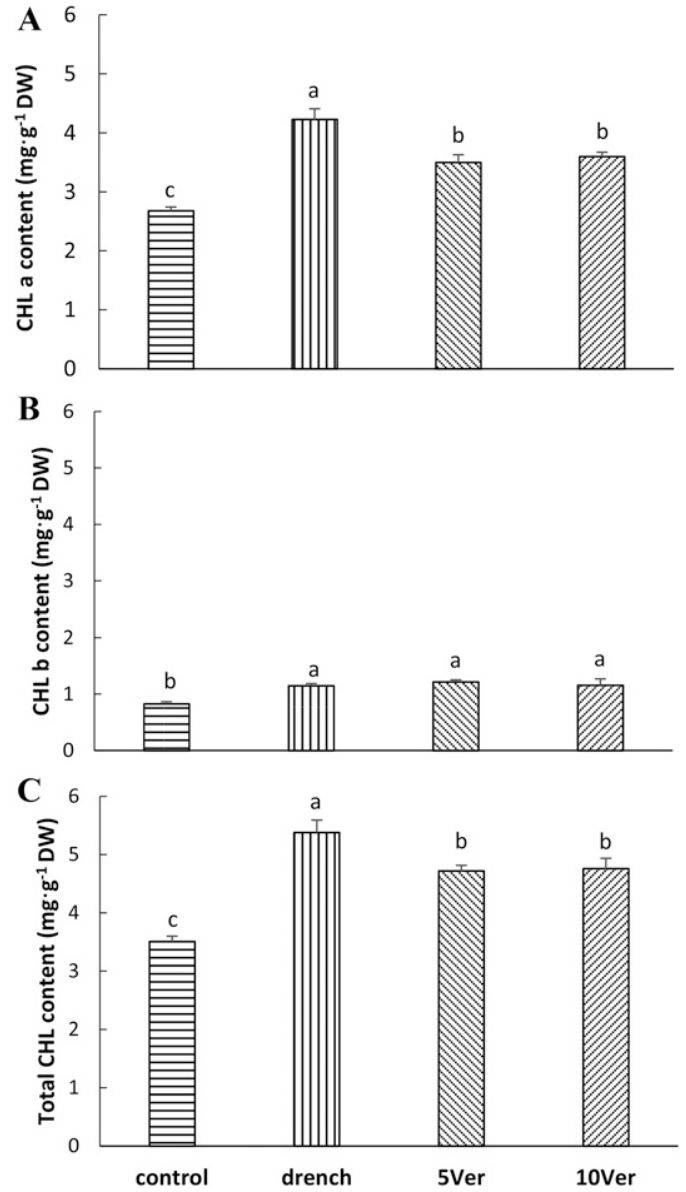

Fig. 5. Effect of vermicompost on spinach chlorophyll (CHL) a (A), CHL b (B), and total CHL contents (C) $35 \mathrm{~d}$ after transplanting. The values are means of eight replicates \pm SE. Different letters on top of bars indicate significant difference at $P \leq 0.05$ according to Student's $t$ test. Drench: $40 \mathrm{~mL}$ of vermicompost extract at 0 , 14,21 , and $28 \mathrm{~d}$ after transplanting; 5Ver or 10 Ver: soil amended with $5 \%$ or $10 \%(\mathrm{v} / \mathrm{v})$ vermicompost.
$0.85 \mathrm{~mL}$ distilled water and $50 \mu \mathrm{L}$ of $5 \%$ $\mathrm{NaNO}_{2}$. After $6 \mathrm{~min}, 100 \mu \mathrm{L}$ of $10 \%$ $\mathrm{AlCl}_{3} \cdot 6 \mathrm{H}_{2} \mathrm{O}$ was added, and after another $5 \mathrm{~min}, 0.35 \mathrm{~mL}$ of $1 \mathrm{~m} \mathrm{NaOH}$ and $0.20 \mathrm{~mL}$ distilled water were added, then $\mathrm{A}_{510}$ was measured immediately (Dewanto et al., 2002). A (+)-catechin hydrate equivalents (CHE) standard curve was prepared from a freshly made solution.

Protein and amino acid contents. Leaf samples (about $2 \mathrm{~g}$ ) were homogenized in $15 \mathrm{~mL} 0.2 \mathrm{~m}$ phosphate buffer ( $\mathrm{pH}$ 6.6) using a homogenizer. After centrifuging at $9070 g_{n}$ for $15 \mathrm{~min}$, the supernatant was collected to measure the content of protein and amino acid. Amino acid content was determined using the ninhydrin method (Yokoyama and Hiramatsu, 2003). A 1\% w/v ninhydrin stock solution was prepared in ethanol containing $0.025 \% \mathrm{w} / \mathrm{v}$ ascorbic acid. A working ninhydrin solution was prepared immediately before use by adding two parts of $0.4 \mathrm{M}$ sodium acetate buffer ( $\mathrm{pH}$ 5.0) to one part of ninhydrin stock solution. Extract or standard glutamate solution $(50 \mu \mathrm{L})$ was added to $2.9 \mathrm{~mL}$ ninhydrin work solution and the mixture was heated at $95{ }^{\circ} \mathrm{C}$ for $10 \mathrm{~min}$. The solution was cooled and $\mathrm{A}_{570}$ was measured. Protein content was determined according to the method of Bradford (1976) using bovine serum albumin as standard.

Statistical analysis. A complete randomized design was used for this experiment. Each biological replicate contained one pot and each treatment included four replicate pots for each trial. Treatment means were separated by Student's $t$ test at the 0.05 level of probability using the JMP program version 5 (SAS Institute Inc., Cary, NC). The interaction of the two trials was not significant, so data were pooled together.

\section{Results}

Soil physical and chemical properties. The granular vermicompost contained high levels of macro- $\left(\mathrm{N}, \mathrm{P}, \mathrm{K}, \mathrm{Ca}, \mathrm{Mg}\right.$, and $\left.\mathrm{SO}_{4}\right)$ and micronutrients $(\mathrm{Cu}, \mathrm{Zn}, \mathrm{Fe}, \mathrm{Mn}$, and $\mathrm{B})$, and organic matter and carbon (Table 1). However, it also had high levels of $\mathrm{Na}$ $\left(9.8 \mathrm{~g} \cdot \mathrm{kg}^{-1}\right)$ and $\mathrm{Cl}\left(13 \mathrm{~g} \cdot \mathrm{kg}^{-1}\right)$ with high EC value $\left(26 \mathrm{dS} \cdot \mathrm{m}^{-1}\right)$. The $\mathrm{C}: \mathrm{N}$ ratio of solid vermicompost was 9.3. After harvesting, the amendments left high residual levels of nutrients $\left(\mathrm{P}, \mathrm{K}, \mathrm{SO}_{4}, \mathrm{Cu}, \mathrm{Zn}, \mathrm{Fe}\right.$, and $\left.\mathrm{B}\right)$, organic matter and carbon, and increased soil CEC and WHC. However, the soil EC increased from 0.58 to 0.92 and $1.4 \mathrm{dS} \cdot \mathrm{m}^{-1}$ with $5 \%$ and $10 \%$ amendments, respectively. The drench treatment increased, to a lesser extent, soil levels of $\mathrm{P}, \mathrm{Mg}, \mathrm{SO}_{4}, \mathrm{Cu}, \mathrm{Zn}, \mathrm{Fe}$, and $\mathrm{B}$. Drench treatment increased soil CEC and WHC, although it had negligible effects on organic matter and carbon.

Growth and physiological responses. Compared with the control, all vermicompost treatments (drench, 5Ver, and 10Ver) significantly increased leaf number from 14.0 to 15.3, 17.0, and 19.8 per plant (Fig. 1A); area from 155 to 252,314 , and 473 (Fig. 1B); FW from 8.7 to $14.3,20.7$, and $33 \mathrm{~g}$ per plant 

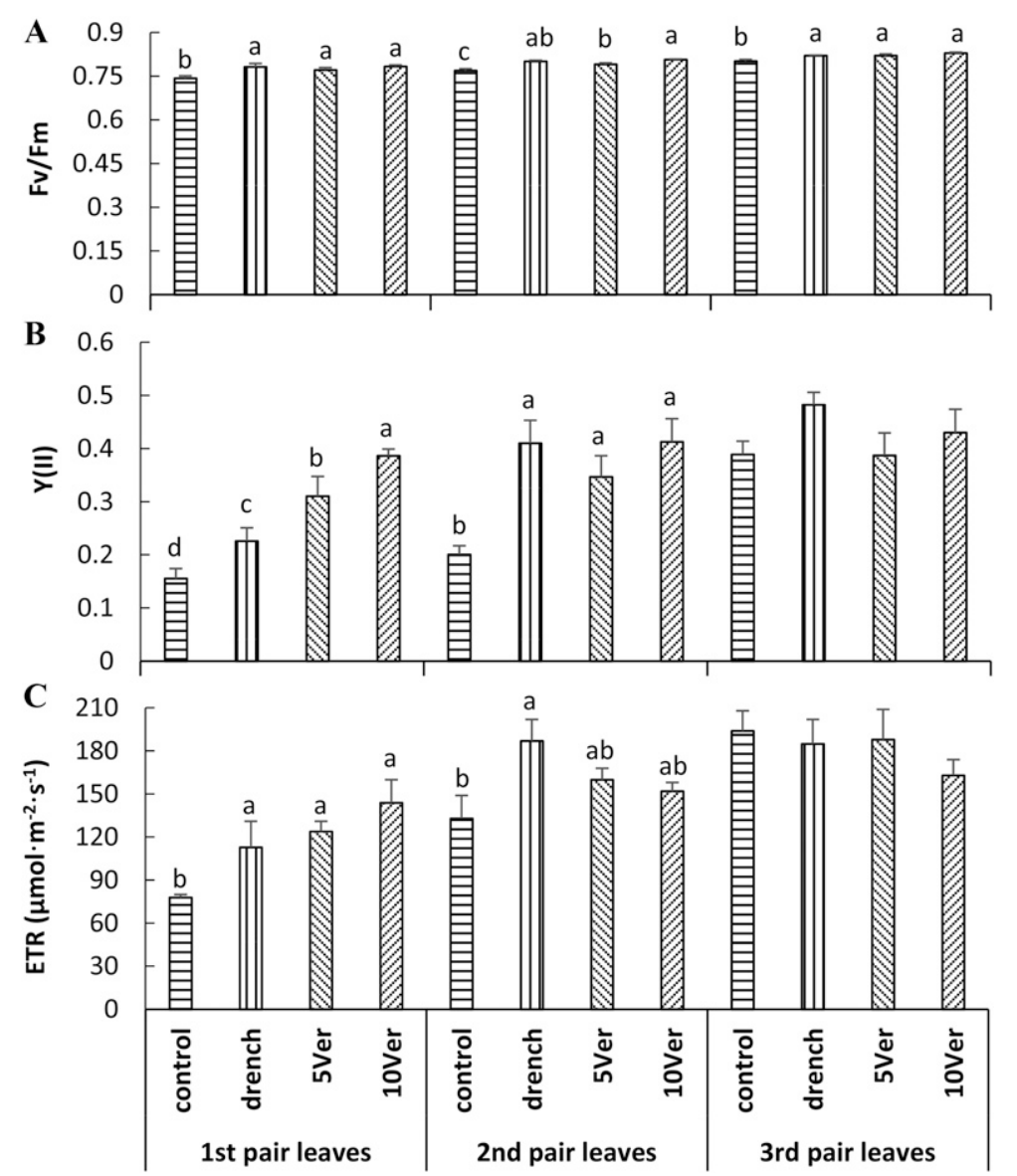

Fig. 6. Effect of vermicompost on spinach leaf photochemical efficiency $\left(\mathrm{F}_{\mathrm{v}} / \mathrm{F}_{\mathrm{m}} ; \mathbf{A}\right)$, photochemical yield [Y(II); B], and electron transport rate (ETR; C) $35 \mathrm{~d}$ after transplanting. The values are means of eight replicates \pm SE. Different letters on top of bars indicate significant difference at $P \leq 0.05$ according to Student's $t$ test. Drench: $40 \mathrm{~mL}$ of vermicompost extract at 0,14,21, and $28 \mathrm{~d}$ after transplanting; $5 \mathrm{Ver}$ or 10 Ver: soil amended with $5 \%$ or $10 \%(\mathrm{v} / \mathrm{v})$ vermicompost.

(Fig. 1C); and DW from 1.5 to 2.5, 3.3, and 5.3 g per plant (Fig. 1D), respectively. Shoot FW significantly increased from 10.6 to 17.5 , 24.4, and 39.6 g per plant (Fig. 2A); DW from 1.8 to $3.1,3.9$, and $6.3 \mathrm{~g}$ per plant (Fig. $2 \mathrm{C}$ ); and WUE from 3.4 to $5.8,6.9$, and $11.3 \mathrm{mg} \cdot \mathrm{mL}^{-1} \mathrm{H}_{2} \mathrm{O}$ (Fig. 2B); by drench, 5Ver, and 10 Ver treatments, respectively. Shoot FW:DW ratio was unaffected by vermicompost treatments (Fig. 2D).

Root DW significantly increased from 0.56 to $0.84,0.84$, and $1.03 \mathrm{~g}$ per plant, in response to the drench, $5 \mathrm{Ver}$, and $10 \mathrm{Ver}$ treatments, respectively (Fig. 3A). Shoot: root FW ratio increased from 3.3 to 4.9 (5Ver) and 6.6 (10Ver), whereas the drench treatment had no effect (Fig. 3B). Leaf RWC was not influenced by any vermicompost treatments (data not shown). The 10Ver treatment decreased SLA, from 134 to 121 $\mathrm{cm}^{2} \cdot \mathrm{g}^{-1}$ DW (Fig. 4A). The two soil amendment treatments increased leaf succulence, from 413 to 505 and $510 \mathrm{H}_{2} \mathrm{O} \mathrm{g} \cdot \mathrm{m}^{-2}$, respectively (Fig. 4B).

Drench, 5Ver, and 10Ver significantly increased chlorophyll-a content from 2.7 to $4.2,3.5$, and $3.6 \mathrm{mg} \cdot \mathrm{g}^{-1} \mathrm{DW}$, respectively (Fig. 5A), chlorophyll b content from 0.83 to $1.15,1.22$, and $1.16 \mathrm{mg} \cdot \mathrm{g}^{-1} \mathrm{DW}$, respectively
(Fig. 5B), and total chlorophyll content from 3.5 to $5.4,4.7$, and $4.8 \mathrm{mg} \cdot \mathrm{g}^{-1} \mathrm{DW}$, respectively (Fig. 5C). All vermicompost treatments significantly increased $\mathrm{F}_{\mathrm{v}} / \mathrm{F}_{\mathrm{m}}$ over the control in the first, second, and third pair leaves, and increased Y(II) and ETR in the first and second pairs of leaves, but not in the third pair of leaves (Fig. 6).

Nutritional values. Leaf carotenoid content significantly increased from 1.4 to 1.9 , 1.7 , and $1.8 \mathrm{mg} \cdot \mathrm{g}^{-1} \mathrm{DW}$ under drench, 5Ver, and $10 \mathrm{Ver}$ treatments, respectively (Fig. 7A). Soil amendments significantly decreased total phenolic content from 17.6 to 14.9 and 13.1 GAE $\mathrm{mg} \cdot \mathrm{g}^{-1} \mathrm{DW}$, respectively, whereas the drench treatment had no effect (Fig. 7B). Betacyanin content significantly decreased from 62 to 51,38 , and $32 \mu \mathrm{g} \cdot \mathrm{g}^{-1} \mathrm{DW}$ under drench, 5Ver, and $10 \mathrm{Ver}$ treatments, respectively (Fig. 7C).

Soil amendments significantly reduced leaf flavonoid content from 3.3 to 2.8 (5Ver) and 2.5 (10Ver) CHE mg.g ${ }^{-1}$ DW (Fig. 8A), and total antioxidant capacity from 175 to 153 and $147 \mathrm{TE} \mathrm{mg} \cdot \mathrm{g}^{-1} \mathrm{DW}$, respectively, whereas the drench treatment did not alter flavonoid content or antioxidant capacity (Fig. 8B). Compared with control, drench and 10 Ver treatment significantly increased leaf amino acid content from 114 to 150 and $158 \mu \mathrm{mol} \cdot \mathrm{g}^{-1} \mathrm{DW}$, respectively (Fig. 9A). Protein content significantly increased from 36 to 55,47 , and $59 \mathrm{mg} \cdot \mathrm{g}^{-1} \mathrm{DW}$ under drench, 5Ver, and 10Ver treatments, respectively (Fig. 9B).

\section{Discussion}

Soil fertility. The vermicompost used in the present study had preferable $\mathrm{C}: \mathrm{N}$ ratio of 9.3. A C:N ratio less than 20 indicates acceptable maturity of the product, but a ratio less than 15 is preferred (Gaur and Sadasivam, 1993; Jimenez and Garcia, 1992). Similar to previous studies (Fornes et al., 2012; Padmavathiamma et al., 2008), the vermicompost has many favorable properties including high content of organic matter and carbon, and macro- and micronutrients, in spite of the high EC value due to its high contents of $\mathrm{Na}$ and Cl. This suggests that a high application rate as soil amendment is not recommended because of the salinity stress it might cause. Even after harvesting, soil with vermicompost amendments, especially at $10 \%$ rate, had high content of nutrients, organic matter and carbon, and high values of CEC and WHC. Also drench treatment increased soil nutrient contents, CEC, and WHC. The results indicate that vermicompost could be used to improve soil fertility as a soil amendment or drench.

Growth and physiological responses. All vermicompost treatments, especially amendment at $10 \%$ rate, greatly stimulated spinach growth, as indicated by increased leaf number, area, FW and DW, shoot FW and DW, and root DW, and shoot growth was more favorably influenced than root growth by soil amendment. Peyvast et al. (2008a) reported that spinach plants with $10 \%$ vermicompost as soil amendment had highest leaf number, area, and FW. Numerous studies indicated that vermicompost amendment into soilless media in greenhouse resulted in increased germination, growth and flowering of ornamentals, and growth and yield of vegetables even at low mix rates (Arancon et al., 2008; Atiyeh et al., 1999, 2000a, 2000b, 2001). In addition, Peyvast et al. (2008b) reported that vermicompost as soil amendments enhanced parsley leaf FW and DW, root DW, and plant height in greenhouse. Similarly, in another greenhouse study, vermicompost as soil amendments increased mustard root and shoot length, numbers of branches, leaves, flowers and pods, and plant FW and DW (Srivastava et al., 2011). Favorable effects of vermicomposts as soil amendments have been reported in field studies on the growth and yield of peppers, tomatoes, and strawberries (Arancon et al., 2003a, 2004, 2005a).

Although vermicompost contains macroand micronutrients, its positive effects on crop growth and yield may not be mainly due to its nutrients, since in some studies, the nutrients in vermicompost were equalized in the control plots treated with inorganic fertilizers (Arancon et al., 2003a, 

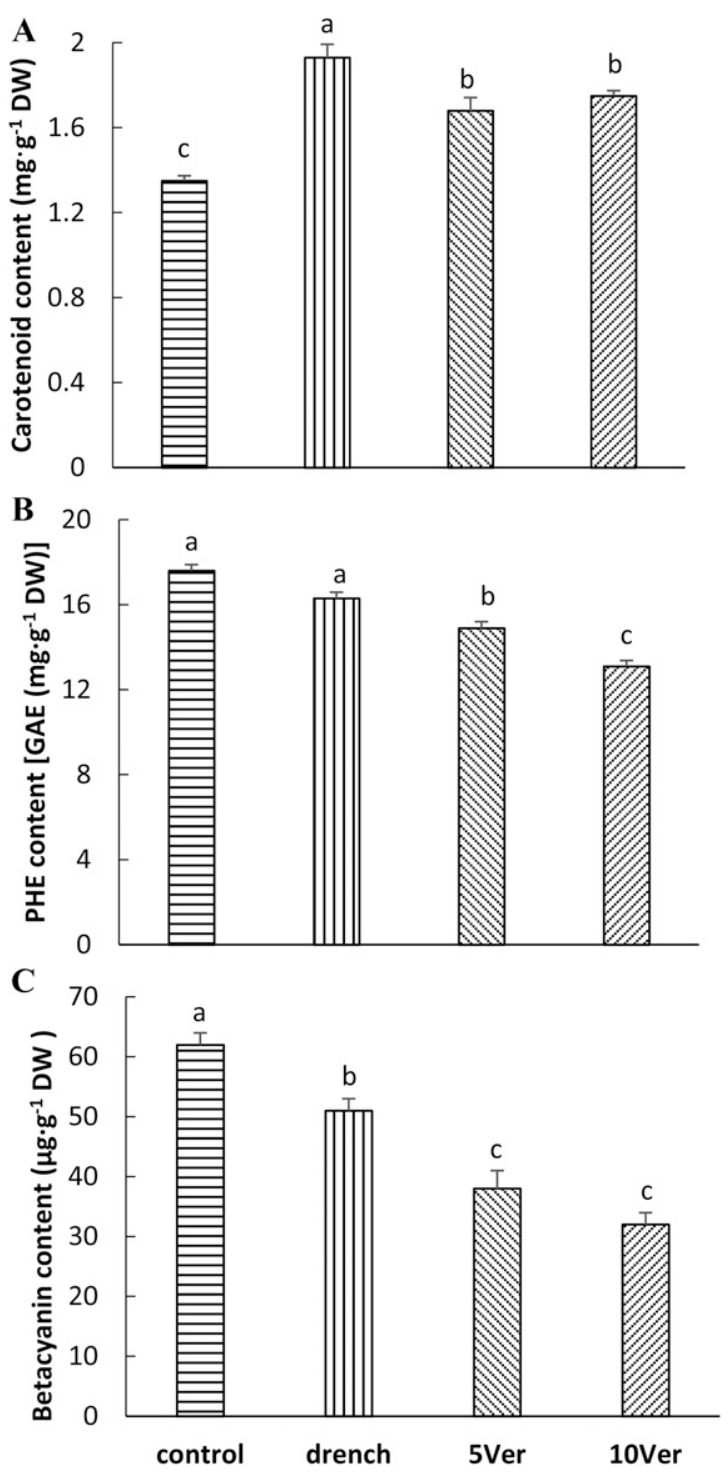

Fig. 7. Effect of vermicompost on spinach leaf carotenoid (A), total phenolic (PHE; B), and betacyanin content (C) $35 \mathrm{~d}$ after transplanting. The values are means of eight replicates \pm SE. Different letters on top of bars indicate significant difference at $P \leq 0.05$ according to Student's $t$ test. Drench: $40 \mathrm{~mL}$ of vermicompost extract at $0,14,21$, and $28 \mathrm{~d}$ after transplanting; 5 Ver or 10 Ver: soil amended with $5 \%$ or $10 \%(\mathrm{v} / \mathrm{v})$ vermicompost. GAE = gallic acid equivalents.

2004, 2005a; Atiyeh et al., 2000a, 2000c, 2002a). The synergetic effects of many factors, such as improved physical structure of soil and nutrient availability, increased microbial biomass and activities, suppression of plant disease, insect and nematode, and biologically active plant growth regulators and humic acid, may have been responsible for the growth stimulation by vermicompost. During vermicomposting process, microorganisms biochemically degrade organic matter and earthworms physically fragment the substrate leading to new nutrient pools and large surface area, which provides nutrients in forms that are readily taken up by the plants such as nitrates, exchangeable $\mathrm{P}$, and soluble K, Ca, and Mg (Orozco et al., 1996), and strong absorption capability and retention of nutrients (Padmavathiamma et al., 2008; Srivastava et al., 2011). Vermicompost is a finely divided peat-like material, and its addition to soil can cause significant changes in physical and chemical properties. Our results indicated that vermicompost enhanced soil organic matter, CEC, and WHC. Similarly, Ferreras et al. (2006) reported that vermicompost as soil amendment improved soil porosity and aggregate ability. Gopinath et al. (2008) observed decreases in soil bulk density and increases in soil $\mathrm{pH}$ and organic carbon after addition of vermicompost. These changes in soil properties improved the availability of air and water, enhancing root growth, which in turn facilitates water and nutrient absorption.

Earthworms can enhance microbial biomass and activities due to their mucus and casts, which were responsible for better litter decomposition and mineralization and provided high amount of available forms of nutrients (Atiyeh et al., 2000b; Padmavathiamma et al., 2008; Srivastava et al., 2011; Tognetti et al., 2005). The byproducts of microbial activities, polysaccharides, can help the aggregation of soil particles. Other products of microbial activities include plant growth-regulating substances such as auxins, gibberellins, cytokinins, ethylene, and abscisic acids (Arancon et al., 2012; Frankenberger and Arshad, 1995; Tomati et al., 1987, 1988). In addition, humic materials from vermicomposts increased plant growth of carrots, tomatoes, and peppers (Arancon et al., 2003c, 2006b; Atiyeh et al., 2002b; Muscolo et al., 1999). Atiyeh et al. (2002b) and Arancon et al. (2003c, 2006b) suggested that humic acid may absorb plant hormones and/or itself has hormone ability to affect plant growth. Actually, Canellas et al. (2002) found that the identified auxin groups in humic acids from vermicompost could enhance root elongation, lateral root emergency, and plasma membrane $\mathrm{H}^{+}$-ATPase activity. Mora et al. (2010) observed that action of humic acid on promotion of cucumber shoot growth involves nitrate-related changes associated with the root-to-shoot distribution of cytokinins, polyamines, and mineral nutrients.

In addition, some studies have shown that vermicompost can suppress a wide range of microbial disease (Edwards et al., 2006), insect pest (Arancon et al., 2005b, 2007; Ramesh, 2000; Yardim et al., 2006), and parasitic nematodes (Arancon et al., 2003b; Swathi et al., 1998). As mentioned above, vermicompost increased soil microbial biomass and activity and changed the diversity and abundance of soil fauna, and thus a broader range of microorganisms may act as biocontrol agents through competition, antibiosis, and parasitism (Lazcano and Domínguez, 2011). Also, the induction of plant systemic resistance by vermicompost was observed by Singh et al. (2003).

All vermicompost treatments increased spinach WUE, which might at least partly result from improved soil properties, such as soil WHC. Vermicompost as soil amendments reduced SLA at $10 \%$ mix rate and increased leaf succulence, indicating the improvement of spinach quality. There are limited reports on chlorophyll content and photochemistry of photosystem II as affected by vermicompost. In this study, chlorophyll content increased under all vermicompost treatments, especially drench treatment. Vermicompost was also reported to increase chlorophyll content in marigold (Atiyeh et al., 2001) and mustard (Srivastava et al., 2011) leaves. In the present study, vermicompost treatments improved photochemistry of photosystem II, especially in mature leaves. They enhanced ETR and Y(II) of both first and second pair leaves, and $\mathrm{F}_{\mathrm{v}} / \mathrm{F}_{\mathrm{m}}$ of all leaves. Parameters related to photochemistry of photosystem II and chlorophyll content are commonly used as indicators for leaf senescence (Adams III et al., 1990; Lima et al., 1999; Plesnićar et al., 1994). The result suggested that vermicompost could delay leaf senescence and extend leaf longevity. Similarly, the positive role of vermicompost in leaf production and longevity was reported 

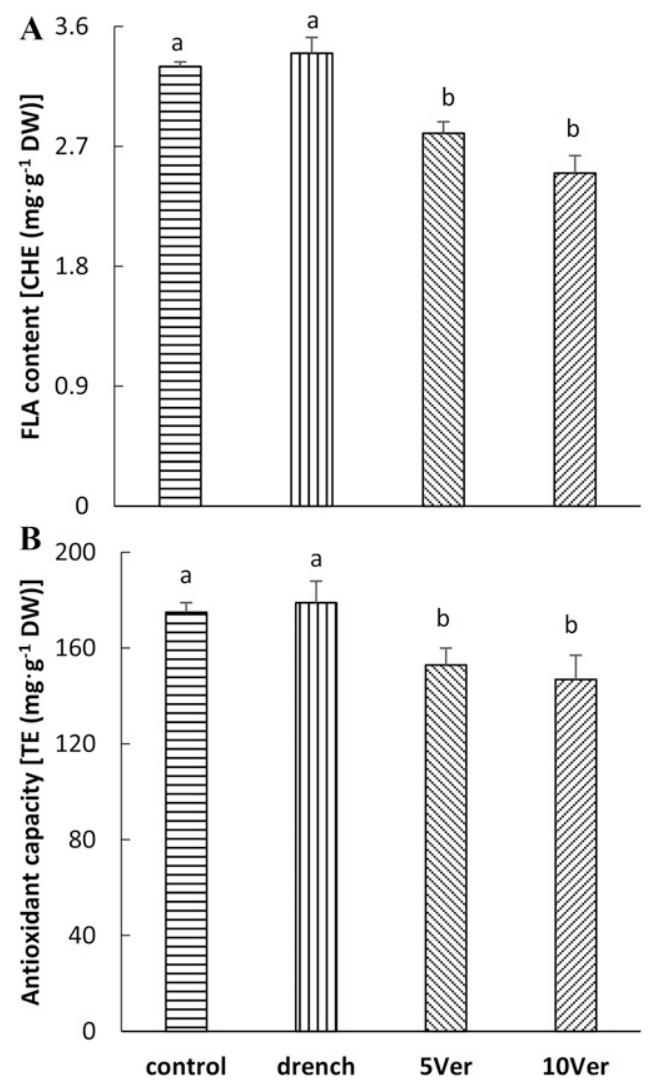

Fig. 8. Effect of vermicompost on spinach leaf flavonoid content (FLA; A) and total antioxidant capacity (B) $35 \mathrm{~d}$ after transplanting. The values are means of eight replicates $\pm \mathrm{SE}$. Different letters on top of bars indicate significant difference at $P \leq 0.05$ according to Student's $t$ test. Drench: $40 \mathrm{~mL}$ of vermicompost extract at 0 , 14,21 , and $28 \mathrm{~d}$ after transplanting; 5 Ver or 10 Ver: soil amended with $5 \%$ or $10 \%(\mathrm{v} / \mathrm{v})$ vermicompost. $\mathrm{CHE}=(+)$-catechin hydrate equivalents; $\mathrm{TE}=$ trolox equivalents.
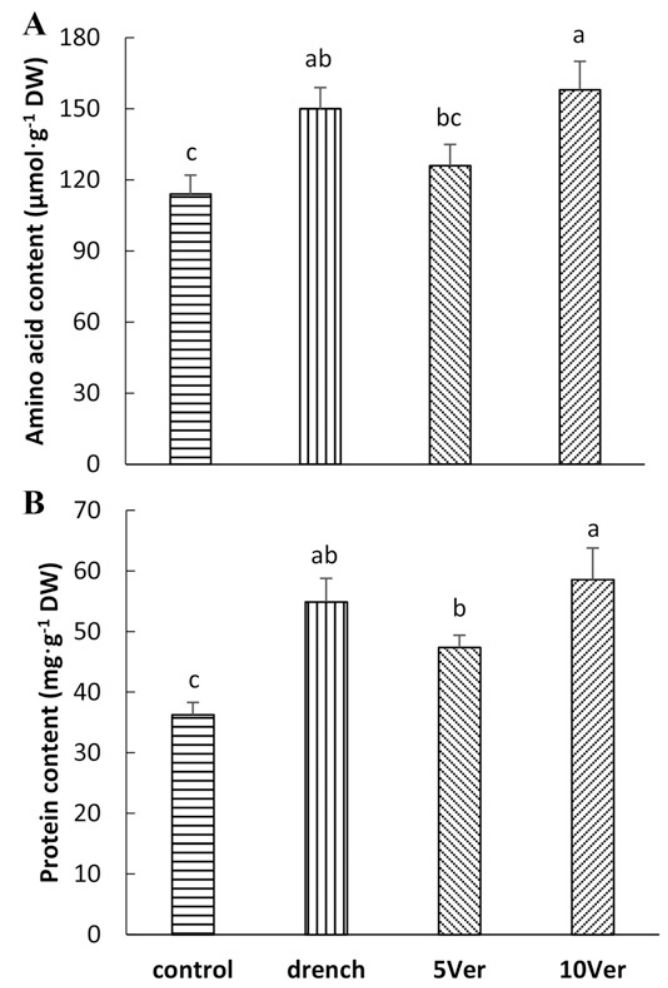

Fig. 9. Effect of vermicompost on spinach leaf amino acid (A) and protein content (B) $35 \mathrm{~d}$ after transplanting. The values are means of eight replicates $\pm \mathrm{SE}$. Different letters on top of bars indicate significant difference at $P \leq 0.05$ according to Student's $t$ test. Drench: $40 \mathrm{~mL}$ of vermicompost extract at $0,14,21$, and $28 \mathrm{~d}$ after transplanting; 5 Ver or 10 Ver: soil amended with $5 \%$ or $10 \%(\mathrm{v} / \mathrm{v})$ vermicompost.

in strawberry, banana, and cassava (Arancon et al., 2004; Padmavathiamma et al., 2008). High number of functional leaves is essential for crop production, especially for leafy vegetable such as spinach.

Nutritional values. Carotenoids have long been recognized as essential nutrients and important health-beneficial compounds (Fraser and Bramley, 2004). Consistent with previous study in mustard and pak choi (Pant et al., 2009; Srivastava et al., 2011), its content increased under all vermicompost treatments, especially under drench treatment, in the present study. However, vermicompost as soil amendment, especially at $10 \%$ rate, reduced the content of other phytochemicals such as phenolics, betacyanins, and flavonoids, and drench treatment only reduced betacyanin content in the present study. Phenolics are a class of secondary metabolites that play a key role as antioxidants. The most important group of phenolics in plants is flavonoids, which have attracted considerable interest due to their broad spectrum of biological effects such as antioxidative, anti-inflammatory, vasorelaxant, antimicrobial, antiviral, and for their anticarcinogenic and antimutagenic activities (Guo et al., 2011; Maimoona et al., 2011). In the present study, only vermicompost as amendment decreased total antioxidant capacity, and the response pattern of total antioxidant capacity was very similar with that of flavonoids, suggesting that flavonoids might be the main antioxidant phytochemical in spinach leaves, at least of this cultivar. Its content might not be negatively altered by drench treatment of vermicompost. There are a few reports about vermicompost's effects on crop phytochemical content. Previous study indicated that vermicompost tea decreased phenolic content in pak choi (Pant et al., 2009). Zaller (2006) reported that ascorbic acid content in tomato fruits decreased after foliar spraying of vermicompost extract.

Vermicompost, whether as an amendment or a drench, also favorably influenced spinach's nutritional value in the present study by increasing protein and amino acid contents. A previous study also indicated that protein content in mustard leaves was greatly increased by vermicompost (Srivastava et al., 2011). In addition, vermicompost was reported to increase sugar content in banana (Padmavathiamma et al., 2008), mustard (Srivastava et al., 2011), spinach, and parsley (Peyvast et al., 2008a, 2008b). Foliar application of vermicompost extract did not alter the content of glucose or fructose in tomato fruit (Zaller, 2006). The information about vermicompost's effect on mineral content was very limited and inconsistent, probably due to different application methods. Vermicompost leachate had no effects on $\mathrm{N}, \mathrm{P}$, and $\mathrm{K}$ concentration in sorghum leaves (Gutiérrez-Miceli et al., 2008). Foliar application of vermicompost extract did not alter mineral content of tomato fruit (Zaller, 2006), whereas soil amendment increased mineral content in spinach and parsley 
(Peyvast et al., 2008a, 2008b). The effect of vermicompost on spinach sugar and mineral content was not assessed in the present study, but deserves further investigation.

In summary, vermicompost improved soil fertility, prompted leaf production, delayed leaf senescence, enhanced spinach growth and WUE. It also improved spinach quality by increasing succulence and the content of carotenoid, protein, and amino acid, although as soil amendment it reduced flavonoid content, leading to low antioxidant capacity. Vermicompost as soil amendment or drench for spinach production in the field might be an efficient strategy for water savings, and organic production, as well as recycling of organic waste materials. Further research should be conducted to investigate its longterm effect and optimize its application rates in the field.

\section{Literature Cited}

Adams, W.W., III, K. Winter, U. Schreiber, and P. Schramel. 1990. Photosynthesis and chlorophyll fluorescence characteristics in relationship to changes in pigment and element composition of leaves of Platanus occidentalis L. during autumnal leaf senescence. Plant Physiol. 92:1184-1190.

Arancon, N.Q., C.A. Edwards, A. Babenko, J. Cannon, P. Galvis, and J.D. Metzger. 2008. Influences of vermicomposts, produced by earthworms and microorganisms from cattle manure, food waste and paper waste, on the germination, growth and flowering of petunias in the greenhouse. Appl. Soil Ecol. 39:91-99.

Arancon, N.Q., C.A. Edwards, and P. Bierman. 2006a. Influences of vermicomposts on field strawberries: Part 2. Effects on soil microbiological and chemical properties. Bioresource Technol. 97:831-840.

Arancon, N.Q., C.A. Edwards, P. Bierman, J.D. Metzger, and C. Lucht. 2005a. Effects of vermicomposts produced from cattle manure, food waste and paper waste on the growth and yield of peppers in the field. Pedobiologia (Jena) 49:297-306.

Arancon, N.Q., C.A. Edwards, P. Bierman, C. Welch, and J.D. Metzger. 2003a. Effects of vermicomposts on growth and marketable fruits of field-grown tomatoes, peppers and strawberries. Pedobiologia (Jena) 47:731-735.

Arancon, N.Q., C.A. Edwards, P. Bierman, C. Welch, and J.D. Metzger. 2004. Influences of vermicomposts on field strawberries: 1. Effects on growth and yields. Bioresource Technol. 93:145-153.

Arancon, N.Q., C.A. Edwards, S. Lee, and R. Byrne. 2006b. Effects of humic acids from vermicomposts on plant growth. Eur. J. Soil Biol. 42:S65-S69.

Arancon, N.Q., C.A. Edwards, E.N. Yardim, T.J. Oliver, R.J. Byrne, and G. Keeney. 2007. Suppression of two-spotted spider mite (Tetranychus urticae), mealy bug (Pseudococcus sp.) and aphid (Myzus persicae) populations and damage by vermicomposts. Crop Protection 26:29-39.

Arancon, N.Q., P.A. Galvis, and C.A. Edwards. 2005b. Suppression of insect pest populations and damage to plants by vermicompost. Bioresource Technol. 96:1137-1142.

Arancon, N.Q., P. Galvis, C.A. Edwards, and E. Yardim. 2003b. The trophic diversity of nematode communities in soils treated with vermicompost. Pedobiologia (Jena) 47:736-740.
Arancon, N.Q., S. Lee, C.A. Edwards, and R.M. Atiyeh. 2003c. Effects of humic acids derived from cattle, food and paper-waste vermicomposts on growth of greenhouse plants. Pedobiologia (Jena) 47:741-744.

Arancon, N.Q., A. Pant, T. Radovich, N.V. Hue, J.K. Potter, and C.E. Converse. 2012. Seed germination and seedling growth of tomato and lettuce as affected by vermicompost water extracts (Teas). HortScience 47:1722-1728.

Atiyeh, R.M., N.Q. Arancon, C.A. Edwards, and J.D. Metzger. 2000a. Influence of earthwormprocessed pig manure on the growth and yield of greenhouse tomatoes. Bioresource Technol. 75:175-180.

Atiyeh, R.M., N.Q. Arancon, C.A. Edwards, and J.D. Metzger. 2001. The influence of earthwormprocessed pig manure on the growth and productivity of marigolds. Bioresource Technol. 81:103-108.

Atiyeh, R.M., N.Q. Arancon, C.A. Edwards, and J.D. Metzger. 2002a. The influence of earthwormprocessed pig manure on the growth and productivity of marigolds. Bioresource Technol. 81:103-108.

Atiyeh, R.M., J. Dominguez, S. Subler, and C.A. Edwards. 2000b. Changes in biochemical properties of cow manure during processing by earthworms (Eisenia andrei, Bouché) and the effects on seedling growth. Pedobiologia (Jena) 44:709-724.

Atiyeh, R.M., C.A. Edwards, S. Subler, and J.D. Metzger. 2000c. Earthworm processed organic wastes as components of horticultural potting media for growing marigolds and vegetable seedlings. Compost Sci. Util. 8:215-223.

Atiyeh, R.M., S. Lee, C.A. Edwards, N.Q. Arancon, and J.D. Metzger. 2002b. The influence of humic acids derived from organic wastes on plant growth. Bioresource Technol. 84:7-14.

Atiyeh, R.M., S. Subler, C.A. Edwards, and J.D Metzger. 1999. Growth of tomato plants in horticultural media amended with vermicompost. Pedobiologia (Jena) 43:724-728.

Barr, H.D. and P.E. Weatherley. 1962. A reexamination of the relative turgidity technique for estimating water deficit in leaves. Austral. J. Biol. Sci. 15:413-428.

Benzie, I.F.F. and J.J. Strain. 1996. The ferric reducing ability of plasma (FRAP) as a measure of "antioxidant power": The FRAP assay. Anal. Biochem. 239:70-76.

Bradford, M.M. 1976. A rapid and sensitive method for the quantitation of microgram quantities of protein utilizing the principle of protein-dye binding. Anal. Biochem. 72:248-254.

Canellas, L.P., F.L. Olivares, A.L. Okorokova, and A.R. Facanha. 2002. Humic acids isolated from earthworm compost enhance root elongation, lateral root emergence, and plasma $\mathrm{H}^{+}$-ATPase activity in maize roots. Plant Physiol. 130:1951-1957.

Dewanto, V., X. Wu, K.K. Adom, and R.H. Liu. 2002. Thermal processing enhances the nutritional value of tomatoes by increasing total antioxidant activity. J. Agr. Food Chem. 50:3010-3014.

D'Hose, Y., M. Cougnon, A. De Vliegher, B. Vandecasteele, N. Viaene, W. Cornelis, E. Van Bockstaele, and D. Reheul. 2014. The positive relationship between soil quality and crop production: A case study on the effect of farm compost application. Appl. Soil Ecol. 75:189-198

Edwards, C.A., N.Q. Arancon, and S. Greytak. 2006. Effects of vermicompost teas on plant growth and disease. Biocycle 47:28-31.
Evans, G.C. 1972. The quantitative analysis of plant growth. University of California Press, Berkeley, CA.

Ferreras, L., E. Gomez, S. Toresani, I. Firpo, and R. Rotondo. 2006. Effect of organic amendments on some physical, chemical and biological properties in a horticultural soil. Bioresource Technol. 97:635-640.

Fornes, F., D. Mendoza-Hernández, R. García-de-laFuente, M. Abad, and R.M. Belda. 2012. Composting versus vermicomposting: A comparative study of organic matter evolution through straight and combined processes. Bioresource Technol. 118:296-305.

Frankenberger, W.T. and M. Arshad. 1995. Phytohormones in soils: Microbial production and function. Marcel and Dekker, New York, NY.

Fraser, P.D. and P.M. Bramley. 2004. The biosynthesis and nutritional uses of carotenoids. Prog. Lipid Res. 43:228-265.

Gaur, A.C. and K.V. Sadasivam. 1993. Theory and practical considerations of composting organic wastes, p. 1-20. In: P.K. Thampan (ed.). Organics in soil health and crop production. Peekay Tree Crops Development Foundation, Cochin, India.

Gopinath, K.A., S. Saha, B.L. Mina, H. Pande, S. Kundu, and H.S. Gupta. 2008. Influence of organic amendments on growth, yield and quality of wheat and on soil properties during transition to organic production. Nutr. Cycl. Agroecosyst 82:51-60.

Guo, T., L. Wei, J. Sun, C. Hou, and L. Fan. 2011. Antioxidant activities of extract and fractions from Tuber indicum Cooke \& Massee. Food Chem. 127:1634-1640.

Gutiérrez-Miceli, F.A., R.C. García-Gómez, R.R. Rosales, M. Abud-Archila, O.L.M. Angela, M.J.G. Cruz, and L. Dendooven. 2008. Formulation of a liquid fertilizer for sorghum (Sorghum bicolor (L.) Moench) using vermicompost leachate. Bioresource Technol. 99:6174-6180.

Hargreaves, J.C., M.S. Adl, and P.R. Warman. 2008. A review of the use of composted municipal solid waste in agriculture. Agr. Ecosyst. Environ. 123:1-14.

Herrick, J.E. 2000. Soil quality: An indicator of sustainable land management? Appl. Soil Ecol. 15:75-83.

Jimenez, E.I. and V.P. Garcia. 1992. Determination of maturity indexes for city refuses composts. Agr. Ecosyst. Environ. 38:331-343.

Lazcano, C. and J. Domínguez. 2011. The use of vermicompost in sustainable agriculture: Impact on plant growth and soil fertility. In: M. Miransari (ed.). Soil Nutrients. Nova Science Publishers, New York, NY.

Lichtenthaler, H.K. 1987. Chlorophylls and carotenoids-pigments of photosynthetic biomembranes. Methods Enzymol. 148:350-382.

Lima, J.D., P.R. Mosquim, and F.M. Da Matta. 1999. Leaf gas exchange and chlorophyll fluorescence parameters in Phaseolus vulgaris as affected by nitrogen and phosphorus deficiency. Photosynthetica 37:113-121.

Liu, X., S.J. Herbert, A.M. Hashemi, X. Zhang, and G. Ding. 2006. Effects of agricultural management on soil organic matter and carbon transformation-A review. Plant Soil Environ. 52:531-543

Longstreth, D.J. and P.S. Nobel. 1979. Salinity effects on leaf anatomy consequences for photosynthesis. Plant Physiol. 63:700-703.

Maimoona, A., I. Naeem, Z. Saddiqe, and K. Jameel. 2011. A review on biological, nutraceutical and clinical aspects of French maritime pine bark extract. J. Ethnopharmacol. 133:261-277. 
Mora, V., E. Bacaicoa, A.M. Zamarrenno, E. Aguirre, M. Garnica, M. Fuentes, and J.M. García-Mina. 2010. Action of humic acid on promotion of cucumber shoot growth involves nitrate-related changes associated with the root-to-shoot distribution of cytokinins, polyamines and mineral nutrients. J. Plant Physiol. 167:633-642.

Muscolo, A., F. Bovalo, F. Gionfriddo, and S. Nardi. 1999. Earthworm humic matter produces auxinlike effects on Daucus carota cell growth and nitrate metabolism. Soil Biol. Biochem. 31:1303-1311.

Orozco, F.H., J. Cegarra, L.M. Trujillo, and A. Roig. 1996. Vermicomposting of coffee pulp using the earthworm Eisenia fetida: Effects on $\mathrm{C}$ and $\mathrm{N}$ contents and the availability of nutrients. Biol. Fert. Soils 22:162-166.

Padmavathiamma, P.K., L.Y. Li, and U.R. Kumari. 2008. An experimental study of vermi-biowaste composting for agricultural soil improvement. Bioresource Technol. 99:1672-1681.

Pant, A.P., T.J.K. Radovich, N.V. Hue, S.T. Talcott, and K.A. Krenek. 2009. Vermicompost extracts influence growth, mineral nutrients, phytonutrients and antioxidant activity in pak choi (Brassica rapa cv. Bonsai, Chinensis group) grown under vermicompost and chemical fertilizer. J. Sci. Food Agr. 89:2383-2392.

Peyvast, G., J.A. Olfati, S. Madeni, and A. Forghani. 2008a. Effect of vermicompost on the growth and yield of spinach (Spinacia oleracea L.). J. Food Agr. Environ. 6:110-113.
Peyvast, G., J.A. Olfati, S. Madeni, A. Forghani, and H. Samizadeh. 2008b. Vermicompost as a soil supplement to improve growth and yield of parsley. Intl. J. Veg. Sci. 14:82-92.

Plesnićar, M., R. Kastori, N. Petrović, and D. Panković. 1994. Photosynthesis and chlorophyll fluorescence in sunflower (Helianthus annuus L.) leaves as affected by phosphorus nutrition. J. Expt. Bot. 45:919-924.

Ramesh, P. 2000. Effects of vermicomposts and vermicomposting on damage by sucking pests to ground nut (Arachis hypogea). Indian J. Agr. Sci. 70:334.

Schwartz, S.J. and J.H. von Elbe. 1980. Quantitative determination of individual betacyanin pigments by high-performance liquid chromatography. J. Agr. Food Chem. 28:540-543.

Singh, U.P., S. Maurya, and D.P. Singh. 2003. Antifungal activity and induced resistance in pea by aqueous extract of vermicompost and for control of powdery mildew of pea and balsam. Z. Pflanzenkr. Pflanzenschutz 110:544-553.

Slinkard, K. and V.L. Singleton. 1997. Total phenol analysis: Automation and comparison with manual methods. Amer. J. Enol. Viticult. 28:49-55.

Srivastava, P.K., P.C. Singh, M. Gupta, A. Sinha, A. Vaish, A. Shukla, N. Singh, and S.K. Tewari. 2011. Influence of earthworm culture on fertilization potential and biological activities of vermicomposts prepared from different plant wastes. J. Plant Nutr. Soil Sci. 174:420-429.
Swathi, P., K.T. Rao, and P.A. Rao. 1998. Studies on control of root-knot nematode Meloidogyne incognita in tobacco miniseries. Tobacco Res. 1:26-30.

Tognetti, C., F. Laosa, M.J. Mazzarino, and M.T. Hernández. 2005. Composting vs. vermicomposting: A comparison of end product quality. Compost Sci. Util. 13:6-13.

Tomati, U., A. Grappelli, and E. Galli. 1987. The presence of growth regulators in earthworm worked wastes, p. 423-436. In: A.M. Bonvicini Paglioi and P. Omodeo (eds.). On earthworms. Selected symposia and monographs 2. Mucchi Editore, Modena, Italy.

Tomati, U., A. Grappelli, and E. Galli. 1988. The hormone-like effect of earthworm casts on plant growth. Biol. Fert. Soils 5:288-294.

Yardim, E.N., N.A. Arancon, C.A. Edwards, T.J. Oliver, and R.J. Byrne. 2006. Suppression of tomato hornworm (Manduca quinquemaculata) and cucumber beetles (Acalymma vittatum and Diabotrica undecimpunctata) populations and damage by vermicomposts. Pedobiologia (Jena) 50:23-29.

Yokoyama, S. and J.I. Hiramatsu. 2003. A modified ninhydrin reagent using ascorbic acid instead of potassium cyanide. J. Biosci. Bioeng. 95:204-205.

Zaller, J.G. 2006. Foliar spraying of vermicompost extracts: Effects on fruit quality and indications of late-blight suppression of field-grown tomatoes. Biol. Agr. Hort. 24:165-180. 